\title{
EPIDEMIOLOGY OF THE PSYCHOSOMATIC DISEASES
}

\author{
BY \\ M. D. WARREN \\ From the Public Health Department, Hampstead, and the London County Council.
}

The rise in deaths attributed to coronary thrombosis and duodenal ulcer has been widely commented upon. It has been suggested that these two conditions are merely examples of the psychosomatic diseases, the incidence of which has risen directly or consecutively with the rising mental stress associated with an increasingly complex civilization. In this paper certain epidemiological facts relating to selected examples of the psychosomatic diseases are studied, and it is shown that there are such differences in behaviour between the diseases as to suggest that modern civilization cannot adequately account for them.

A study of the many published case reports and clinical investigations leaves no doubt that mental stress plays a large part in precipitating individual attacks and causing exacerbations of the illnesses. Furthermore, mental stress will cause prolonged disability to arise from an illness which in a person with less stress would cause only temporary and trivial disability. If episodes of external stress acted universally in this way, then one would expect to see fluctuations in the incidence of the psychosomatic diseases related to periods of unemployment with more marked rises in the lower social classes, in towns subjected to bombing during the war, etc. Although Swinscow (1951) showed a correlation between suicides and unemployment no such correlations have been shown with the psychosomatic diseases.

For this study the following seven conditions have been selected as representative of the psychosomatic diseases:

(1) Asthma

(2) Thyrotoxicosis

(3) Hypertension-Cerebral haemorrhage-Myocardial degeneration

(4) Coronary artery disease-Coronary thrombosis

(5) Gastric ulcer

(6) Duodenal ulcer

(7) Rheumatoid arthritis

The figures for suicides are also compared. The above diseases have been accepted as psychosomatic by Dunbar (1943), Halliday (1949), and Weiss and
English (1950). They have been selected for this study for the following reasons:

(a) Each can prove fatal and at least during the last 15 years has been recorded as a separate cause of death by the Registrar-General.

(b) Each is representative of one of the main systems of the body.

(c) Each is reasonably distinctive when florid and fully developed, and has been recognized as a clinical entity for at least 50 years.

The majority of the figures used are quoted or calculated from Tables given in the RegistrarGeneral's Annual Statistical Reviews for England and Wales, and therefore refer only to mortality rates. Asthma and rheumatoid arthritis mortality figures can only represent a small proportion of the total incidence, and this must also apply to peptic ulcer figures. But in discussing secular trends and in making comparisons between sexes, classes, etc., there is no reason to presume that this difference between mortality and morbidity figures need invalidate the limited conclusions drawn.

However, in discussing the trends of mortality rates certain difficulties must be emphasized. They include the changes produced by the introduction of the new death certificate in 1927; the alteration in 1940 of the procedure used by the RegistrarGeneral in deciding the principal cause of death where more than one cause was given; changes in the International Classification of Causes of Death; changing fashion and increased accuracy of diagnosis; the effect of improvements in therapeutics.

The difficulties in the interpretation of the occupational and social class incidence have been discussed in detail by Martin. (1945). As the social classes are based on occupation the complications associated with occupational mortality must also be borne in mind. These are:

(1) Geographical limitation of the choice of occupation available. Genetic and family and social factors thereby become confused with occupational factors.

(2) Progression from menial occupations to executive occupations, so that the average age of the 
latter will be higher than that of the former; similarly Social Classes I and II will contain a higher proportion of older people.

(3) Selection of an occupation for health reasons. Thus a person who is, or considers himself, "prone to rheumatism" will probably seek an indoor sitting-down job, as also would an asthmatic subject. An ambitious person brought up in a village will seek his career in the big towns. A person in poor health in the North of England may move to the South seeking more clement weather, and in so doing change his occupation. These considerations apply with equal force in discussing mortality figures for geographical areas. The degree of urbanization affects the social class structure. Thus large towns have the largest proportion of Social Classes IV and V, and the South of England has a high proportion of Class I since the Government and many large commercial firms have their executive and administrative staffs in London.

\section{Statistical Data}

The diseases are classified in the Figure and Tables in accordance with the Sixth Edition of the International Statistical Classification of Diseases, Injuries, and Causes of Death (1948). This edition, which differs considerably from previous editions, was adopted by the RegistrarGeneral with effect from 1950. The diseases discussed below have the following classification numbers:

\section{Asthma 240-241 \\ Thyrotoxicosis 252 \\ Hypertension 440-447 \\ Cerebral haemorrhage 331 \\ Suicide E970-E979}

The comparative mortality indices referring to years before 1940 are in accordance with the previous classifications of the Registrar-General and are therefore not entirely comparable in size to the subsequent indices, but the pattern of incidence is still comparable. These remarks do not apply to myocardial degeneration; this has not been corrected to the sixth edition classification in which hypertension is shown as a separate cause of death for the first time. In order to gain a picture of hypertension before 1950 it has been necessary to consider the incidence of related conditions, and for this purpose cerebral haemorrhage, myocardial degeneration, and arteriosclerotic kidney are considered.

\section{Secular Trends}

The comparative mortality indices of the diseases under consideration are shown graphically in the Figure; the most striking feature being the continuous rise in deaths attributed to coronary artery disease and the fall in deaths since 1938 attributed to thyrotoxicosis. Another striking feature is the similarity in the patterns of incidence between the sexes.
The rise in deaths due to coronary artery disease has been remarked on by many authors. The Registrar-General discussed this in his reports for 1934, 1936, and 1938-9, and particularly considered whether the increase was real or was brought about artificially by a change in classification and certification. He concluded that:

even if the whole of the increase in deaths attributed to coronary disease and angina pectoris has been due to a changing description of deaths formerly attributed to myocardial degeneration, with or without associated arteriosclerosis, the problem of the cause of the rapid increase for the combined group is still unsolved.

Since that time the increase has become even more rapid. Ryle and Russell (1949) made a statistical and clinical study of the recent trends in the incidence of coronary thrombosis and angina and also concluded that there was a definite and marked real increase in coronary artery disease. Morris (1951) also found, as a result of a careful study of necropsy reports at the London Hospital, that there had been a large increase in coronary artery disease. Logan (1952) also concluded that the increase was real.

The cause for the decrease in deaths attributed to thyrotoxicosis was discussed by the RegistrarGeneral (1949), who stated:

No satisfactory explanation for the rapid fall in mor tality since 1938 has been suggested. The introduction of thiouracil on any sufficient scale to influence the deaths rate came too late in the period under review to accoun for the fall. The surgical method of treatment had its greatest vogue before 1939 .

The incidence of mortality due to asthma, cerebral haemorrhage, and cardiovascular degeneration (i.e. hypertension) has remained more or less steady, whilst that due to gastric ulcer and rheumatoid arthritis has decreased since 1940-41, having previously remained more or less stationary. The mortality due to duodenal ulcer increased for males in 1940; it remained higher in the following years, showing two periods of peak incidence in 1941 and 1945, and was again rising in 1950. For females the incidence showed a drop in 1942, a peak in 1945, and a sharp rise in 1949 and 1950. Suicides in males dropped during the war years, rose slightly in 1945-6, and since then has been more or less stationary. The females showed a similar drop in suicides during the war, but have shown a greater increase subsequently.

A further interesting feature of the Figure (opposite) is that all the causes of mortality other than suicide showed a peak incidence between 1939 and 1941, this being most marked in the case of asthma. The explanation of this peak is complex, for there was an increase in deaths from all causes 
MALES
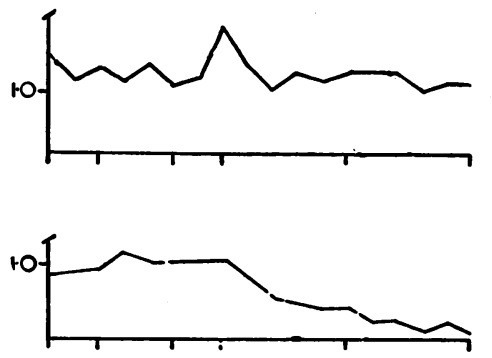

A STHMA

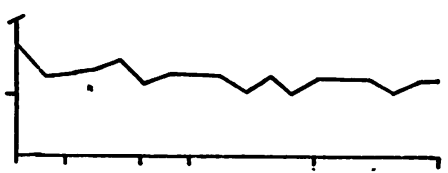

THYROTOXICOSIS

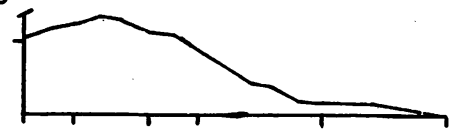

CEREBRAL HAEMORRHAGE
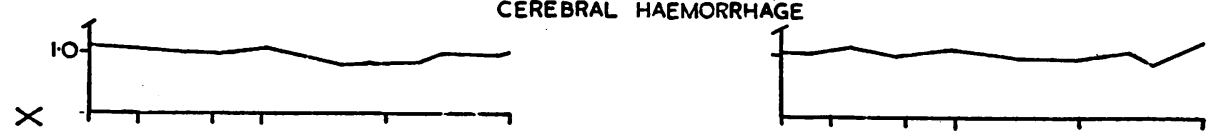

w

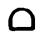

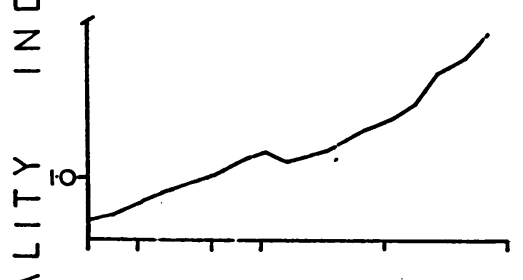
CORONARY DISEASE

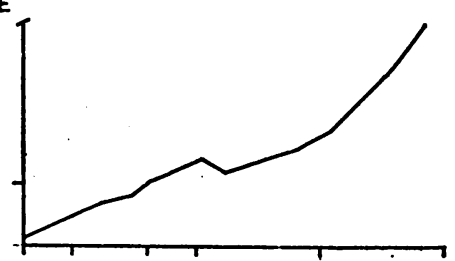

$\varangle$

$\check{\leftarrow}$

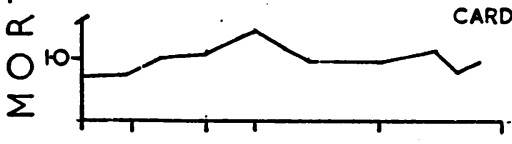

CARDIOVASCULAR DEGENERATION
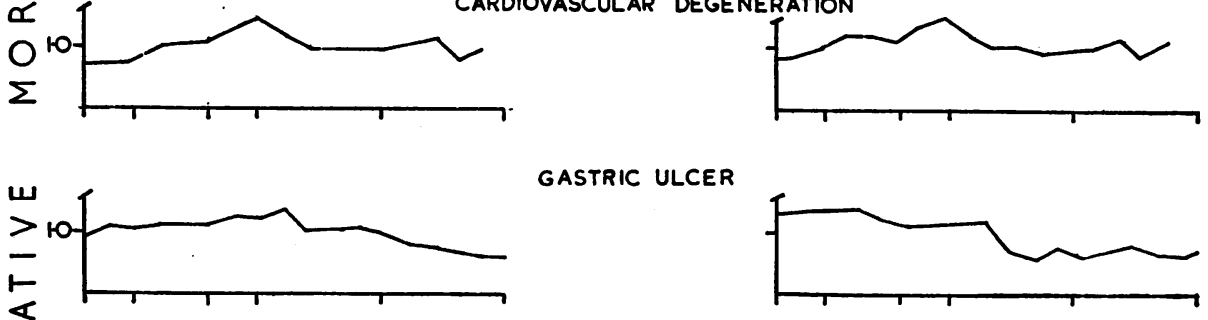

GASTRIC ULCER

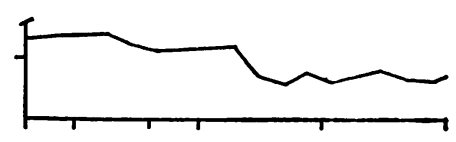

$\propto$

$\varangle$ DUODENAL ULCER
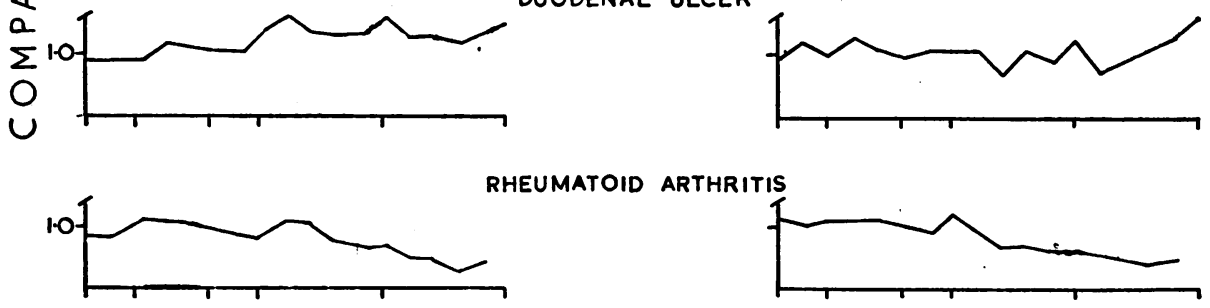

RHEUMATOID ARTHRITIS
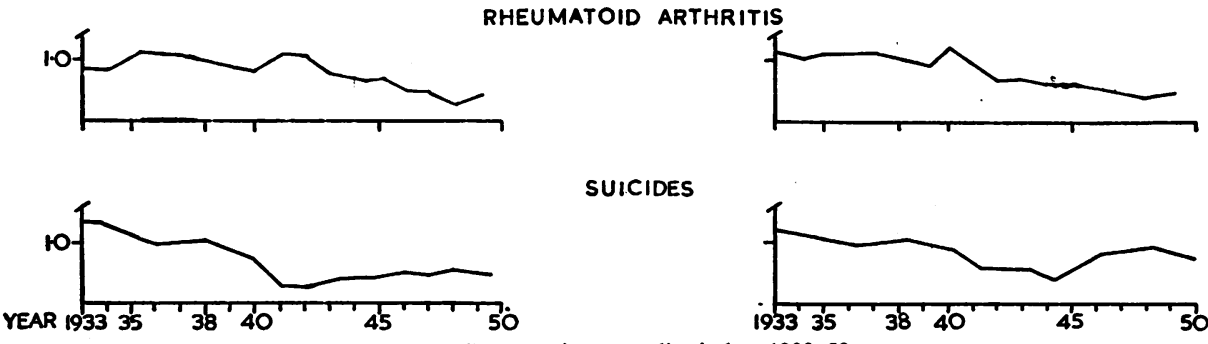

SUICIDES

FIGURE.-Comparative mortality index, 1933-50.

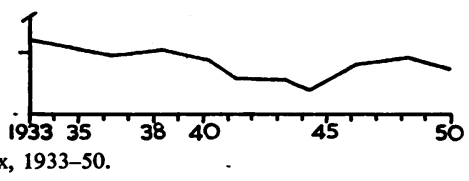


in 1940, and the war-time figures referred to the civilian population so that many healthy and younger persons were excluded. Furthermore there were so many adverse factors (including increased hours of work, introduction of rationing, evacuation, bombing, etc.) that it is extremely difficult to separate any single one. The intensification of rationing in 1944 did not cause any change in mortality from the diseases under discussion, but duodenal ulcer deaths showed an increase in 1945, and it has been suggested that this was due to the stress associated with the increased bombing of the previous year. This suggestion, however, is not supported by the work of Illingworth and others (1944), who showed that the rise in perforations of peptic ulcer in 1940 was present in the West of Scotland as well as in London, though the former area was not subject to air raids at that time.

To sum up the secular trends, the mortality due to thyrotoxicosis, gastric ulcer, and rheumatoid arthritis has fallen, that due to asthma and hypertension has remained more or less level, and that due to coronary disease and duodenal ulcer has increased.

\section{Age InCidence}

Table I shows the number of deaths per million persons living for each sex, for each decade of life from the age of 25 years, and for the years 1931, $1941,1944,1947$, and 1950. These years have been chosen because 1931 was the year of the last census for which full information has been published, and from 1941 every third year was included up to 1950 , the last year for which full figures are available. Table I also shows the relative importance of the deaths attributed to coronary disease, cardiovascular degeneration, and cerebral haemorrhage, which together account for many thousands of deaths, the less striking numbers due to peptic ulcer and suicide, and the very small numbers due to asthma, thyrotoxicosis, and rheumatoid arthritis. These figures however bear little relation to the morbidity from these diseases.

Mortality increases with increasing age, with the exception of thyrotoxicosis and suicide in females. Although it is frequently reported that the psychosomatic diseases affect mainly middle-aged business . and professional men, there was no evidence in 1950 that this referred to the mortality in relation to age. Two hypotheses could account for the increase in mortality with increase in age: First, that it is necessary for the causative factors to operate for a long period of time before death results; thus, if one of these factors is mental stress, then it would be necessary to look back many years to ascertain the exact and particular factor. Second, if the causative factor is of short duration then it must affect the older section of the population more than the younger. As the mortality from these diseases, with the exception of thyrotoxicosis, is associated with concomitant degenerative pathological changes, it could be argued that the mental stress acts as a precipitating or aggravating factor superimposed on degenerative changes such as arteriosclerosis. Whether a life of stress would itself cause arteriosclerosis is another problem. However, there is a further point which is not so speculative. As these diseases are associated with old age, as the age of the population is increasing, as more and more diseases are becoming curable, and as everyone must die eventually, the incidence of diseases associated in any way with degenerative lesions will inevitably increase. Although allowance can be and is made for the ageing population, for example by using the Registrar-General's Comparative Mortality Index*, no allowance can be made for the decrease of deaths due to illnesses now curable.

\section{SEX INCIDENCE}

The differences in incidence between the sexes are also shown in Table I. Asthma causes death slightly more frequently in males than in females. This is probably due to occupational causes of asthma in males. Thyrotoxicosis mortality is greater in females as is also the case with rheumatoid arthritis. Gastric ulcer and hypertension show a modest excess of male deaths, but deaths due to cerebral haemorrhage are almost equal.

In deaths from coronary disease, duodenal ulcer, and suicide the male figures are considerably higher in all age groups. It will be noted that these comparisons between the sexes apply to each decade of life for each year since 1931 .

\section{Social Class Incidence}

Table II shows the standard mortality ratio for each social class for the age group 25 to 64 years for the years 1930-2. These are the deaths related to the number of people reported in each social class as a result of the census of 1931 . Once more, striking differences are seen between the diseases. Thyrotoxicosis is far commoner in Class $\mathrm{V}$ than in Class I, as also, । although to a lesser extent, are cardiovascular degeneration, gastric ulcer, arthritis, and asthma. Coronary disease, duodenal ulcer, and suicide are distinctly commoner in Classes I and II, and cerebral haemorrhage differs in sex incidence, being commoner in Classes I and II in

* This expresses each cause of mortality for each year as a ratio of that for 1938 adopted as the base after adjustment for age differences in the population exposed. 
TABLE I

DEATH RATES PER MILLION LIVING, BY SEX AND AGE

\begin{tabular}{|c|c|c|c|c|c|c|c|c|c|c|c|c|c|}
\hline \multirow{2}{*}{$\begin{array}{c}\text { Cause of } \\
\text { Death }\end{array}$} & \multirow{2}{*}{ Year } & \multicolumn{5}{|c|}{ Male } & & \multicolumn{6}{|c|}{ Female } \\
\hline & & $25-$ & $35-$ & $45-$ & $55-$ & $65-$ & $75-$ & $25-$ & $35-$ & $45-$ & $55-$ & 65 & 75 \\
\hline Asthma & $\begin{array}{l}1931 \\
1941 \\
1950\end{array}$ & $\begin{array}{l}11 \\
13 \\
12\end{array}$ & $\begin{array}{l}42 \\
34 \\
26\end{array}$ & $\begin{array}{l}96 \\
94 \\
89\end{array}$ & $\begin{array}{l}149 \\
144 \\
243\end{array}$ & $\begin{array}{l}320 \\
190 \\
353\end{array}$ & $\begin{array}{l}468 \\
251 \\
361\end{array}$ & $\begin{array}{l}12 \\
14 \\
19\end{array}$ & $\begin{array}{l}24 \\
27 \\
32\end{array}$ & $\begin{array}{l}48 \\
50 \\
74\end{array}$ & $\begin{array}{r}113 \\
84 \\
138\end{array}$ & $\begin{array}{l}238 \\
125 \\
221\end{array}$ & $\begin{array}{l}320 \\
164 \\
289\end{array}$ \\
\hline $\begin{array}{l}\text { Thyrotoxi- } \\
\text { cosis }\end{array}$ & $\begin{array}{l}1931 \\
1941 \\
1944 \\
1947 \\
1950 \\
\end{array}$ & $\begin{array}{r}4 \\
4 \\
1 \\
1 \\
-\quad \\
\end{array}$ & $\begin{array}{l}7 \\
6 \\
4 \\
2 \\
3 \\
\end{array}$ & $\begin{array}{r}13 \\
15 \\
9 \\
7 \\
2 \\
\end{array}$ & $\begin{array}{l}18 \\
22 \\
14 \\
10 \\
13 \\
\end{array}$ & $\begin{array}{l}12 \\
15 \\
12 \\
13 \\
11 \\
\end{array}$ & \begin{tabular}{r|}
11 \\
17 \\
4 \\
7 \\
5 \\
\end{tabular} & $\begin{array}{r}30 \\
14 \\
9 \\
6 \\
3 \\
\end{array}$ & $\begin{array}{r}60 \\
31 \\
17 \\
13 \\
7 \\
\end{array}$ & $\begin{array}{r}104 \\
69 \\
47 \\
40 \\
25 \\
\end{array}$ & $\begin{array}{r}128 \\
99 \\
65 \\
71 \\
63 \\
\end{array}$ & $\begin{array}{r}103 \\
112 \\
88 \\
110 \\
83 \\
\end{array}$ & $\begin{array}{l}53 \\
64 \\
49 \\
68 \\
76\end{array}$ \\
\hline $\begin{array}{l}\text { Cerebral } \\
\text { Haemorrhage }\end{array}$ & $\begin{array}{c}1931-35 \\
1941 \\
1944 \\
1947 \\
1950\end{array}$ & $\begin{array}{l}14 \\
25 \\
34 \\
20 \\
12\end{array}$ & $\begin{array}{r}79 \\
79 \\
107 \\
78 \\
55\end{array}$ & $\begin{array}{l}402 \\
375 \\
408 \\
383 \\
293\end{array}$ & $\begin{array}{l}1,590 \\
1,461 \\
1,439 \\
1,374 \\
1,168\end{array}$ & $\begin{array}{l}5,310 \\
4,212 \\
4,110 \\
4,067 \\
3,676\end{array}$ & $\begin{array}{r}11,937 \\
9,783 \\
8,639 \\
9,474 \\
8,410\end{array}$ & $\begin{array}{l}15 \\
20 \\
20 \\
22 \\
12\end{array}$ & $\begin{array}{l}78 \\
80 \\
89 \\
96 \\
62\end{array}$ & $\begin{array}{l}465 \\
498 \\
471 \\
449 \\
399\end{array}$ & $\begin{array}{l}1,511 \\
1,466 \\
1,466 \\
1,418 \\
1,221\end{array}$ & $\begin{array}{l}4,633 \\
4,065 \\
4,032 \\
4,100 \\
3,600\end{array}$ & $\begin{array}{r}10,815 \\
8,909 \\
8,456 \\
9,494 \\
8,766\end{array}$ \\
\hline $\begin{array}{c}\text { Coronary } \\
\text { Disease }\end{array}$ & $\begin{array}{l}1931 \\
1941 \\
1944 \\
1947 \\
1950\end{array}$ & $\begin{array}{r}8 \\
11 \\
20 \\
22 \\
32\end{array}$ & $\begin{array}{r}55 \\
127 \\
161 \\
216 \\
268\end{array}$ & $\begin{array}{r}252 \\
621 \\
790 \\
1,054 \\
1,368\end{array}$ & $\begin{array}{r}745 \\
1,781 \\
2,195 \\
2,940 \\
4,257\end{array}$ & $\begin{array}{l}1,593 \\
3,526 \\
4,469 \\
6,050 \\
9,028\end{array}$ & $\begin{array}{r}2,005 \\
5,095 \\
5,847 \\
8,647 \\
14,240\end{array}$ & $\begin{array}{l}3 \\
7 \\
5 \\
6 \\
6\end{array}$ & $\begin{array}{l}10 \\
23 \\
26 \\
34 \\
38\end{array}$ & $\begin{array}{r}45 \\
118 \\
145 \\
180 \\
243\end{array}$ & $\begin{array}{r}220 \\
531 \\
627 \\
804 \\
1,253\end{array}$ & $\begin{array}{r}\quad 628 \\
1,599 \\
1,911 \\
2,628 \\
4,353\end{array}$ & $\begin{array}{l}1,022 \\
2,781 \\
3,222 \\
4,779 \\
8,569\end{array}$ \\
\hline $\begin{array}{r}\text { Cardio- } \\
\text { vascular } \\
\text { Degenera- } \\
\text { tion }\end{array}$ & $\begin{array}{l}1931 \\
1941 \\
1944 \\
1947\end{array}$ & $\begin{array}{l}0 \\
3 \\
4 \\
2 \\
\end{array}$ & $\begin{array}{r}9 \\
19 \\
10 \\
13\end{array}$ & $\begin{array}{r}79 \\
118 \\
87 \\
126\end{array}$ & $\begin{array}{l}520 \\
805 \\
747 \\
804\end{array}$ & $\begin{array}{l}2,544 \\
3,494 \\
3,350 \\
3,865\end{array}$ & $\begin{array}{r}7,855 \\
12,019 \\
11,482 \\
14,848\end{array}$ & $\begin{array}{l}1 \\
2 \\
1 \\
0\end{array}$ & $\begin{array}{l}4 \\
9 \\
8 \\
9\end{array}$ & $\begin{array}{l}52 \\
80 \\
62 \\
73\end{array}$ & $\begin{array}{l}323 \\
457 \\
388 \\
457\end{array}$ & $\begin{array}{l}1,516 \\
2,373 \\
2,257 \\
2,742\end{array}$ & $\begin{array}{r}5,864 \\
9,028 \\
9,293 \\
11,911\end{array}$ \\
\hline $\begin{array}{l}\text { Arterio- } \\
\text { sclerotic } \\
\text { Kidney }\end{array}$ & $\begin{array}{l}1941 \\
1944 \\
1947\end{array}$ & $\begin{array}{l}24 \\
44 \\
18\end{array}$ & $\begin{array}{l}49 \\
48 \\
40\end{array}$ & $\begin{array}{l}145 \\
132 \\
123\end{array}$ & $\begin{array}{l}402 \\
309 \\
332\end{array}$ & $\begin{array}{r}1,002 \\
760 \\
803\end{array}$ & $\begin{array}{l}2,437 \\
2,032 \\
2,416\end{array}$ & $\begin{array}{l}18 \\
19 \\
14\end{array}$ & $\begin{array}{l}41 \\
42 \\
43\end{array}$ & $\begin{array}{r}116 \\
99 \\
104\end{array}$ & $\begin{array}{l}294 \\
222 \\
231\end{array}$ & $\begin{array}{l}697 \\
585 \\
563\end{array}$ & $\begin{array}{l}1,585 \\
1,365 \\
1,590\end{array}$ \\
\hline Hypertension & 1950 & 12 & 49 & 226 & 822 & 2,470 & 5,701 & 10 & 33 & 167 & 575 & 1,861 & 4,903 \\
\hline Gastric Ulcer & $\begin{array}{c}1931-33 \\
1940-42 \\
1943-45 \\
1947 \\
1950\end{array}$ & $\begin{array}{r}47 \\
41 \\
40 \\
14 \\
9\end{array}$ & $\begin{array}{r}124 \\
117 \\
98 \\
64 \\
40\end{array}$ & $\begin{array}{l}256 \\
248 \\
213 \\
169 \\
107\end{array}$ & $\begin{array}{l}297 \\
433 \\
382 \\
297 \\
281\end{array}$ & $\begin{array}{l}317 \\
432 \\
408 \\
416 \\
456\end{array}$ & $\begin{array}{l}297 \\
431 \\
377 \\
500 \\
592\end{array}$ & $\begin{array}{r}10 \\
8 \\
7 \\
3 \\
3\end{array}$ & $\begin{array}{l}31 \\
20 \\
13 \\
11 \\
9\end{array}$ & $\begin{array}{l}77 \\
47 \\
35 \\
35 \\
22\end{array}$ & $\begin{array}{r}115 \\
100 \\
77 \\
77 \\
65\end{array}$ & $\begin{array}{l}154 \\
165 \\
138 \\
146 \\
148\end{array}$ & $\begin{array}{l}188 \\
238 \\
195 \\
283 \\
310\end{array}$ \\
\hline $\begin{array}{l}\text { Duodenal } \\
\text { Ulcer }\end{array}$ & \begin{tabular}{|c|}
$1931-33$ \\
$1940-42$ \\
$1943-45$ \\
1947 \\
1950
\end{tabular} & $\begin{array}{l}33 \\
33 \\
40 \\
22 \\
17\end{array}$ & $\begin{array}{l}73 \\
80 \\
86 \\
63 \\
49\end{array}$ & $\begin{array}{l}136 \\
149 \\
147 \\
138 \\
134\end{array}$ & $\begin{array}{r}161 \\
243 \\
222 \\
228 \\
-\quad 233\end{array}$ & $\begin{array}{l}179 \\
255 \\
253 \\
263 \\
370\end{array}$ & $\begin{array}{l}187 \\
250 \\
248 \\
295 \\
413\end{array}$ & $\begin{array}{l}5 \\
3 \\
3 \\
2 \\
2\end{array}$ & $\begin{array}{l}7 \\
7 \\
8 \\
5 \\
6\end{array}$ & $\begin{array}{l}16 \\
15 \\
16 \\
10 \\
14\end{array}$ & $\begin{array}{l}24 \\
26 \\
26 \\
18 \\
33\end{array}$ & $\begin{array}{l}34 \\
43 \\
41 \\
51 \\
60\end{array}$ & $\begin{array}{r}54 \\
54 \\
58 \\
75 \\
111\end{array}$ \\
\hline $\begin{array}{c}\text { Rheumatoid } \\
\text { Arthritis }\end{array}$ & $\begin{array}{l}1939 \\
1941 \\
1944 \\
1947 \\
1950\end{array}$ & $\begin{array}{l}2 \\
2 \\
2 \\
1 \\
1\end{array}$ & $\begin{array}{l}\bar{z} \\
\frac{7}{3}\end{array}$ & $\begin{array}{r}13 \\
11 \\
12 \\
6 \\
2\end{array}$ & $\begin{array}{l}37 \\
40 \\
35 \\
34 \\
18\end{array}$ & $\begin{array}{r}98 \\
105 \\
82 \\
65 \\
34\end{array}$ & $\begin{array}{l}202 \\
272 \\
194 \\
185 \\
105\end{array}$ & $\begin{array}{r}5 \\
6 \\
4 \\
3 \\
-\end{array}$ & $\begin{array}{l}\bar{z} \\
\frac{7}{4}\end{array}$ & $\begin{array}{l}27 \\
25 \\
23 \\
21 \\
11\end{array}$ & $\begin{array}{l}86 \\
75 \\
68 \\
52 \\
29\end{array}$ & $\begin{array}{r}240 \\
242 \\
193 \\
173 \\
97\end{array}$ & $\begin{array}{l}489 \\
504 \\
397 \\
371 \\
271\end{array}$ \\
\hline Suicide & \begin{tabular}{|c|}
$1931-35$ \\
1941 \\
1944 \\
1947 \\
1950
\end{tabular} & $\begin{array}{r}141 \\
100 \\
108 \\
85 \\
70\end{array}$ & $\begin{array}{l}209 \\
130 \\
126 \\
114 \\
122\end{array}$ & $\begin{array}{l}379 \\
180 \\
190 \\
207 \\
222\end{array}$ & $\begin{array}{l}542 \\
295 \\
269 \\
314 \\
323\end{array}$ & $\begin{array}{l}534 \\
374 \\
332 \\
383 \\
416\end{array}$ & $\begin{array}{l}483 \\
414 \\
395 \\
480 \\
421\end{array}$ & $\begin{array}{l}77 \\
55 \\
48 \\
51 \\
35\end{array}$ & $\begin{array}{r}108 \\
70 \\
74 \\
80 \\
75\end{array}$ & $\begin{array}{r}153 \\
113 \\
97 \\
134 \\
124\end{array}$ & $\begin{array}{l}165 \\
140 \\
118 \\
160 \\
157\end{array}$ & $\begin{array}{r}135 \\
117 \\
114 \\
166 \\
153\end{array}$ & $\begin{array}{r}84 \\
67 \\
70 \\
114 \\
115\end{array}$ \\
\hline
\end{tabular}

TABLE II

STANDARD MORTALITY RATIO BY SOCIAL CLASS IN AGE GROUP 25-65 1930-32

\begin{tabular}{|c|c|c|c|c|c|c|c|c|c|c|c|c|c|c|c|c|c|c|}
\hline \multirow{2}{*}{$\begin{array}{l}\text { Disease } \\
\text { Sex. . }\end{array}$} & \multirow{2}{*}{$\cdots$} & \multirow{2}{*}{$\begin{array}{l}\cdot \\
\cdots \\
\cdots\end{array}$} & \multirow{2}{*}{$\frac{\cdots}{\cdots}$} & \multicolumn{2}{|c|}{ Asthma } & \multirow{2}{*}{$\frac{\begin{array}{c}\text { Thyrotoxi- } \\
\text { cosis }\end{array}}{\text { F }}$} & \multicolumn{2}{|c|}{$\begin{array}{c}\text { Cerebral } \\
\text { Haemorr- } \\
\text { hage }\end{array}$} & \multicolumn{2}{|c|}{$\begin{array}{l}\text { Coronary } \\
\text { Disease }\end{array}$} & \multicolumn{2}{|c|}{$\begin{array}{c}\text { Cardio- } \\
\text { vascular } \\
\text { Degenera- } \\
\text { tion }\end{array}$} & \multirow{2}{*}{$\begin{array}{c}\begin{array}{c}\text { Gastric } \\
\text { Ulcer }\end{array} \\
\mathbf{M}\end{array}$} & \multirow{2}{*}{$\begin{array}{c}\begin{array}{c}\text { Duodenal } \\
\text { Ulcer }\end{array} \\
\mathbf{M}\end{array}$} & \multicolumn{2}{|c|}{ Arthritis } & \multicolumn{2}{|c|}{ Suicide } \\
\hline & & & & $\mathbf{M}$ & $\mathbf{F}$ & & $\mathbf{M}$ & $\mathbf{F}$ & $\mathbf{M}$ & $\mathbf{F}$ & $\mathbf{M}$ & $\mathbf{F}$ & & & $\mathbf{M}$ & $\mathbf{F}$ & $\mathbf{M}$ & $\mathbf{F}$ \\
\hline \multirow{4}{*}{$\underset{\text { Class }}{\text { Social }}$} & & I & & \multirow{2}{*}{ ! 89} & \multirow{2}{*}{88} & \multirow{2}{*}{59} & 112 & 75 & 237 & 157 & 77 & 54 & 55 & 101 & \multirow{2}{*}{90} & \multirow{2}{*}{91} & 128 & 128 \\
\hline & & II & & & & & 106 & 90 & 148 & 126 & 92 & 75 & 76 & 106 & & & 151 & 135 \\
\hline & & III & & 102 & 106 & 93 & 101 & 101 & 95 & 93 & 94 & 99 & 99 & 99 & 98 & 102 & 94 & 95 \\
\hline & & IV & & 105 & 98 & 89 & 96 & 108 & 66 & 84 & 105 & 110 & 109 & 93 & 115 & 106 & 95 & 85 \\
\hline • & & $\mathbf{V}$ & & 106 & 103 & 196 & 96 & 110 & 67 & 89 & 122 & 129 & 127 & 107 & 103 & 103 & 90 & 87 \\
\hline
\end{tabular}


males and in Classes IV and V in females. Recent studies have shown that the present social class incidence, although similar to that of 1931 , has shown some levelling off (Logan, 1952; Doll and Avery-Jones, 1951).

\section{GEOGRAPHICAL INCIDENCE}

Table III shows the differences between England and Wales generally (taken as 100 ) as compared with Greater London, the County Boroughs, the Urban Districts, and the Rural Districts. Some idea may thus be obtained of the effect of urbanization upon the death rates. Cardiovascular degeneration, coronary disease, duodenal ulcer in males, gastric ulcer in males and females (except in London), and suicide in females show a decrease in mortality with a decrease in urbanization; thyrotoxicosis shows the reverse trend, and cerebral haemorrhage although lower in.London is more or less equal in the rest of the country.

\section{SEASONAL INCIDENCE}

The Registrar-General's Annual Statistical Review for 1949 (Medical Table No. 23, not reproduced here) shows the number of deaths occurring from each cause by months. The incidence of asthma, cerebral haemorrhage, myocardial degeneration, coronary disease, and peptic ulcer is lowest from June to October. The incidence of suicide is highest at that season, and thyrotoxicosis and rheumatoid arthritis show little seasonal variation.

\section{OCCUPATIONAL INCIDENCE}

A study of the occupations associated with the highest death rates from these diseases reveals trends similar to those already described in connection with social class and geographical incidence. Thyrotoxicosis is found most commonly in the wives of farmers, gardeners, nurserymen, retail proprietors, carpenters, and agricultural labourers- a marked preponderance of rural occupations. Coronary disease is most marked in doctors, wholesale proprietors, lawyers, and clergymen, all members of Class I. Hypertension and cerebral haemorrhage are more common in hotel-keepers, barmen, textile dyers, furnacemen, rollers, and grinders. Duodenal ulcers, gastric ulcers, rheumatoid arthritis, and asthma occur in diverse occupational groups including coal-miners (particularly asthma and "arthritis"), typists, clerks, managers, and general labourers. In 1931 fheumatoid arthritis was not shown separately from other forms of arthritis, and there is little doubt that, among the coal-miners particularly, asthma and arthritis would include some cases of pneumonoconiosis and traumatic arthritis respectively.

Table IV (opposite) summarizes the foregoing sections; it shows that the three conditions which have decreased in recent years (thyrotoxicosis, gastric ulcers, and rheumatoid arthritis) show a maximum incidence in Social Classes IV and V, and that thyrotoxicosis and rheumatoid arthritis are higher in females. These diseases show little seasonal variation and female cases either show no geographical variation or are more numerous in the rural areas.

By contrast, coronary disease and, to a lessero extent, duodenal ulcer show a definite rise in incidence, a preponderance in males, an excess in Social Classes I and II (coronary disease), an excess in urban areas, and a lower incidence in the spring and summer.

Asthma, cerebral haemorrhage, and myocardial degeneration have remained level, affect males only slightly more than females, tend to occur more frequently in Social Classes IV and V, bear little relation to urbanization, and have a lower incidence in the spring and summer.

TABLE III

GEOGRAPHICAL DISTRIBUTION OF DEATHS, BY SEX

\begin{tabular}{|c|c|c|c|c|c|c|c|c|c|c|c|c|c|c|c|c|c|}
\hline \multicolumn{2}{|c|}{ Source of Information } & $\cdot$ & \multirow[b]{2}{*}{$\cdots$} & \multicolumn{4}{|c|}{$\begin{array}{l}\text { Comparative Mortality } \\
\text { Figure, 1940-44 }\end{array}$} & \multicolumn{10}{|c|}{ Ratio-Deaths per million living, 1947} \\
\hline \multirow{2}{*}{$\begin{array}{l}\text { Disease } \\
\text { Sex .. }\end{array}$} & \multirow{2}{*}{$\cdots$} & \multirow{2}{*}{$\cdots$} & & \multicolumn{2}{|c|}{$\begin{array}{c}\text { Cardio- } \\
\text { vascular } \\
\text { Degeneration }\end{array}$} & \multicolumn{2}{|c|}{$\begin{array}{l}\text { Coronary } \\
\text { Disease }\end{array}$} & \multicolumn{2}{|c|}{$\begin{array}{l}\text { Thyrotoxi- } \\
\text { cosis }\end{array}$} & \multicolumn{2}{|c|}{$\begin{array}{c}\text { Cerebral } \\
\text { Haemorr- } \\
\text { hage }\end{array}$} & \multicolumn{2}{|c|}{$\begin{array}{l}\text { Duodenal } \\
\text { Ulcer }\end{array}$} & \multicolumn{2}{|c|}{$\begin{array}{l}\text { Gastric } \\
\text { Ulcer }\end{array}$} & \multicolumn{2}{|c|}{ Suicide } \\
\hline & & & $\cdots$ & $\mathbf{M}$ & $\mathbf{F}$ & $\mathbf{M}$ & $\mathbf{F}$ & $\mathbf{M}$ & $\mathbf{F}$ & $\mathbf{M}$ & $\mathbf{F}$ & $\mathbf{M}$ & $\mathbf{F}$ & $\mathbf{M}$ & $\mathbf{F}$ & $\mathbf{M}$ & $\mathbf{F}$ \\
\hline \multirow{5}{*}{ Area } & \multicolumn{3}{|c|}{ England and Wales } & 100 & 100 & 100 & 100 & 100 & 100 & 100 & 100 & 100 & 100 & 100 & 100 & 100 & 100 \\
\hline & \multicolumn{3}{|c|}{ Greater London .. } & 107 & 114 & 127 & 124 & 75 & 63 & 82 & 75 & 107 & 100 & 118 & 83 & 93 & 111 \\
\hline & \multicolumn{3}{|c|}{ County Boroughs ... } & 114 & 110 & 100 & 94 & 100 & 86 & 109 & 108 & 115 & 93 & 111 & 113 & 103 & 106 \\
\hline & \multicolumn{3}{|c|}{ Urban Districts } & 95 & 93 & 97 & 98 & 100 & 114 & 107 & 106 & 94 & 100 & 95 & 91 & 99 & 95 \\
\hline & \multicolumn{3}{|c|}{ Rural Districts } & 85 & 86 & 82 & 91 & 100 & 132 & 91 & 103 & 80 & 100 & 73 & 105 & 105 & $82^{\circ}$ \\
\hline
\end{tabular}


TABLE IV

SUMMARY OF TRENDS OF MORTALITY FIGURES, 1931-1950

\begin{tabular}{|c|c|c|c|c|c|c|c|}
\hline Disease & $\begin{array}{l}\text { Secular } \\
\text { Trend }\end{array}$ & $\begin{array}{c}\text { Maximum } \\
\text { Age } \\
\text { Incidence }\end{array}$ & $\begin{array}{c}\text { Sex } \\
\text { Incidence }\end{array}$ & $\begin{array}{l}\text { Social } \\
\text { Class }\end{array}$ & $\begin{array}{l}\text { Geographical } \\
\text { Peak }\end{array}$ & $\underset{\text { Peak }}{\text { Seasonal }}$ & $\begin{array}{l}\text { Associated } \\
\text { Occupation }\end{array}$ \\
\hline Asthma & Level & $65+$ & Male & IV-V & - & Winter & Mixed \\
\hline Thyrotoxicosis & Fall & $55-74$ & Female & $\mathbf{V}$ & Rural & Equal & Rural \\
\hline $\begin{array}{l}\text { Cerebral } \\
\text { Haemorrhage }\end{array}$ & Level & $65+$ & Equal & Equal & Equal & Winter & Mixed \\
\hline $\begin{array}{c}\text { Coronary } \\
\text { Disease }\end{array}$ & Rise & $65+$ & Male & I-II & Urban & Winter & Professional \\
\hline $\begin{array}{c}\text { Myocardial } \\
\text { Degeneration }\end{array}$ & Level & $65+$ & Male & IV-V & Urban & Winter & Mixed \\
\hline Gastric Ulcer & Fall & $65+$ & Male & IV-V & $\begin{array}{l}\text { Urban } \\
\text { (in males) }\end{array}$ & $\begin{array}{l}\text { Autumn- } \\
\text { Spring }\end{array}$ & Mixed \\
\hline Duodenal Ulcer & Rise & $65+$ & Male & Equal & Urban & $\begin{array}{l}\text { Autumn- } \\
\text { Spring }\end{array}$ & Mixed \\
\hline $\begin{array}{c}\text { Rheumatoid } \\
\text { Arthritis }\end{array}$ & Fall & $65+$ & Female & IV-V & - & Equal & Mixed \\
\hline Suicide & Fall & $\begin{array}{l}65 \mathrm{M} \\
55-74 \mathrm{~F}\end{array}$ & Male & I-II & $\begin{array}{l}\text { Urban } \\
\text { (in females) }\end{array}$ & $\begin{array}{l}\text { Spring } \\
\text { Summer }\end{array}$ & Mixed \\
\hline
\end{tabular}

\section{Discussion}

It is frequently suggested that the increasing complexities of town life have caused the present increase in the diseases of stress and strain. However the large towns have a larger proportion of the population in Class $\mathrm{V}$ than the rural areas, and one would expect the effects of urbanization to be associated with a higher incidence in Class $\mathrm{V}$. Further, the monotony of town and factory life, the artificiality of the cinema, etc., fall more heavily on the people of Classes IV and V. The suggestion that the frustration of business life is to blame could not account for the markedly high incidence in the professions and the lower incidence in managers and other business men.

In search of some explanation of these enigmata, many protagonists of psychosomatic medicine have tried to relate personality with disease incidence and have accounted in this way for some of the epidemiological features.

Thus Dunbar (1943), examining a series of inpatients, found that:

Patients with coronary disease have very unusual educational records, showing a marked tendency to complete the academic unit undertaken, and a generally high educational average.

The income of such patients was high, and they manifested an especially clear-cut constellation of personality traits and a typical life pattern of asceticism and hard work enforced by compulsions. Such a description could certainly fit the successful professional man, and those possessing such personalities would tend to rise to Social Classes I and II and to make a career in one of the professions.
Davies and Wilson (1937), Gilsenan (1946), Ryle (1948), and Doll and Avery-Jones (1949; 1951) describe the duodenal ulcer type as cautious, reliable, conscientious, often over-serious, and ambitious. Ryle added a characteristic touch to his description in the following words:

If engaged in business their city lunch is an occasion not for respite and digestion, but for more business.

Such characteristics would be more associated with Classes I and II and such persons would tend to move from the country to the city.

In complete contrast are the personality patterns described in connection with thyrotoxicosis, asthma, and rheumatoid arthritis. Halliday (1942) found marked emotional self-restriction and obsessional trends in his cases of rheumatoid arthritis, Rogerson and others (1935) found an association between asthma in children and over-protectiveness, Rubin and Moses (1944) considered asthmatic sufferers to be fundamentally of a passive dependent type, and Abramson (1951) described them as submissive and obedient. Moschowitz (1930), Conrad (1934), and Lidy and Whitehon (1950) found thyrotoxic patients striving to gain affection and protection from others:

Inordinately insecure, they concentrate their efforts on gaining the affection of a parent, a child, or sometimes a spouse, by self-sacrifice.

Rennie (1939) found a life-long instability, overattention to bodily symptoms, and a smouldering resentment in a selected group of patients with hypertension. Dunbar (1943) found that patients with hypertension had a relatively low educational level and described them as ambitious but assailed 
by doubt, wishing to be in authority and at the same time wishing to be taken care of. These descriptions are compatible with the epidemiological findings, in as much as hypertension occupies an intermediate position between the coronary-duodenal group (ambitious-successful) and the thyrotoxic-arthritic group (dependent-doubting).

The studies of Selye in relation to stress and the general adaptation syndrome (Selye, 1950) also lend support to the broad epidemiological categories of the psychosomatic diseases. Thus coronary artery disease (with increased liability to clotting) and acute gastro-intestinal erosions are manifestations of increased secretions of ACTH and of glucocorticoids, and both conditions are aggravated by cortisone. Carlisle (1950) has also shown that duodenal ulcers and coronary disease are contraindications to the use of cortisone. Asthma, rheumatoid arthritis, and gout (another disease that has decreased in recent years) are manifestations of later stages in the reaction to stress and are quickly reversible by treatment with cortisone. Hypertension is a manifestation of increased somatotrophic hormone and mineralocorticoids and its reaction to cortisone is equivocal, as is also that of thyrotoxicosis.

\section{CONCLUSION}

It is admitted that every illness arises from a constellation of many factors, or to quote Lord Samuel's "Essay in Physics" (1951):

No event can emanate from another single event; no effect is ever the product of one cause, but always of a combination of causes.

Nevertheless the isolation of even minor factors may help towards the elucidation of the whole complex. It is suggested that the present study shows two extreme and opposite types of psychosomatic disease: one associated with the active, ambitious personality, with the "alarm reaction" of Selye, and aggravated by cortisone (examples being coronary disease and duodenal ulcer), and the other associated with the passive, dependent personality, at a later stage of adaptation than the alarm reaction, and able to be relieved by cortisone.

For the first type the mortality rate is increasing, is commoner in males, and in Social Classes I and II, and is seen more commonly in urban areas. For the second type the mortality rate has decreased or remained level, is commoner in females or equal between the sexes, occurs more often in Social Classes IV and V, and shows little difference in distribution between urban and rural areas. These points of contrast seem to suggest that contemporary psychological factors play a greater part in the first type, whilst deeper and more distant psychological factors are dominant in the second group. In both types, of course, psychological factors may cause an exacerbation of an existing illness.

\section{SUMMARY}

(1) A study of the mortality figures for certain psychosomatic diseases shows that there has been an increase in coronary artery disease and duodenal ulcer, and a decrease or levelling off in thyrotoxicosis, asthma, rheumatoid arthritis, and gastric ulcer.

(2) The diseases which have increased are commoner in males and in urban areas.

(3) The diseases which have increased are reported to be associated with ambitious personalities, whilst those which have decreased are associated with dependent personalities.

(4) The diseases which have increased are aggravated by the administration of cortisone, whilst the others are relieved.

(5) The mortality figures provide no evidence to justify the frequent generalization that all the psychosomatic diseases are rapidly increasing because of the complexities of modern civilization. There does however seem to be some evidence that certain groups or types of people are failing to adapt themselves to certain environmental stresses. No evidence regarding the nature of these stresses is adduced.

\section{REFERENCES}

Abramson, H. A., (1951). "Treatment of Asthma". Ballière, Tindall and Cox, London.

Carlisle, J. M., (1950). Brit. med. J., 2, 590.

Conrad, A., (1934). J. nerv. ment. Dis., 79, 505 and 656.

Davies, D. T., and Wilson, A. T. M., (1937). Lancet, 2, 1353.

Doll, R., and Jones, F. Avery, (1949). Practitioner, 162, 44.

(1951). Spec. Rep. Ser. med. Res. Coun., Lond., No. 276. H.M.S.O., London.

Dunbar, F. (1943). "Psychosomatic Diagnosis", New York.

Gilsenan, B. M. C. (1946). Practitioner, 156, 456.

Halliday, J. L. (1942). Proc. roy. Soc. Med., 35, 455.

(1948). "Psychosocial Medicine". Heinemann, London.

Illingworth, C. F. W., Scott, L. D. W., and Jamieson, R. A. (1944). Brit. med. J., 2,617 and 655 .

Lidz, T., and Whitehon, J. C. (1950). "Life Stress and Bodily Disease". Res. Publ. Ass. ner. ment. Dis., 29, 445.

Logan, W. P. D., (1952). Lancet, 1, 758.

Martin, W. J., (1945). Hum. Biol., 17, 1 .

Morris, J. N., (1951). Lancet, 1, 1 and 69.

Moschcowitz, E., (1930). Arch. intern. Med., 46, 610.

Registrar-General. (1930 to 1950). Annual "Statistical Reviews of England and Wales". H.M.S.O., London.

(1938). "Decennial Supplement for England and Wales. 1931. Part IIA. Occupational Mortality". H.M.S.O., London.

Rennie, T. A. C., (1939). New Engl. J. Med., 221, 448.

Rogerson, C. H., Hardcastle, D. H., and Duguid, K. (1935). Guy's Hosp. Rep., 15, 289.

Rubin, S., and Moses, L. (1944). Psychosom. Med., 6, 31.

Ryle, J. A., (1948). "Natural History of Diseases", 2nd ed. Oxford University Press, London.

$\overline{\text { Sely }}$ and Russell, W. T., (1949). Brit. Heart J., 11, 370.

Selye, H., (1950). "Stress". Acta. Inc., Montreal.

Swinscow, D. (1951). Brit. med. J., 1,1417.

Weiss, E., and English, O. S. (1949). "Psychosomatic Medicine", 2nd ed., Saunders, Philadelphia. 